\title{
Kafka er din ven er din Kafka
}

Franz Kafka: Narration, Rhetoric and Reading. Columbus: Ohio University Press, 2011, 251 sider.

I udgangspunktet er det et potentielt problematisk og derfor spændende møde, som redaktørerne af antologien Franz Kafka: Narration, Rhetoric and Reading har bragt i stand: Fra den ene side kommer Kafkas produktion med dens aldrig velkendte uhjemligheder, på en gang underminerende og insisterende på det singulære og enestående ("stubbornly enigmatic", kalder redaktørerne af antologien den). Fra den anden side kommer narratologien, læren om fortællinger, en systembyggende, generaliserende og til tider tendentielt scientistisk bestræbelse, der nok taler om selvberoende genstande, men som oftest bruger dem som eksempler. Mødet bliver ekstra akut i kraft af den valgte slags narratologi, nemlig den retoriske narratologi i arven fra Wayne C. Booth. Den har som en af sine primære præmisser, at alle fortællinger, selv de mest sære af slagsen, er redskaber til at kommunikere med; at fortællinger indpakker indsigter i fortællingens struktur med det formål at lade læserens udpakning af disse indsigter blive en ny indsigt.

Spændende bliver mødet, fordi en retorisk tilgang til Kafka leder lige lukt ind i det måske mest centrale spørgsmål, rejst af og i Kafkas værk: Er litterær produktion en mere egentlig kommunikationsform eller snarere et sidste vidnesbyrd om kommunikationsformernes fallit?

En stor del af antologiens artikler, hvoraf hovedparten er læsninger af enkelttekster og derfor især stærke tekstanalyser, kan deles i to lige store grupper, hvad angår svaret på det spørgsmål. James Phelan, Jakob Lothe, Anniken Greve og Benno Wagner læser Kafkas tekster som udfordret kommunikation, beregnet på at rokke ved læseres verdensbilleder, mens især Gerhard Kurz, Gerhard Neumann og J. Hillis Miller snarere læser Kafkas tekster som kommunikationsnegerende. Som det fremgår, er det a-kæderne fra henholdsvis den retoriske narratologi og Kafka-receptionen, der er kaldt ind, med en svag bias mod det decideret modne. Med Stanley Corngold, Gerhard Kurz, Ronald Speirs og Neumann stiller antolgien med hele fire emeritusser, som alle har været og fortsat er centralt placerede i både diskussionen og disseminationen af Kafkas produktion.

Om de opbyggelige bidrag først. Phelan, der i dag står som den mest indflydelsesrige repræsentant for amerikansk retorisk narratologi, indleder antologien med en artikel, der er lige så sikkert udført, som den er genkendelig i forhold til Phelans øvrige nyere artikler. Først en kort og præcis introduktion til hovedideerne i Phelans version af retorisk narratologi, så udvalgte af disse ideer bragt i anvendelse under en læsning af en litterær tekst (her Kafkas "Dommen"), så en rekursiv bevægelse tilbage til teorien for at se, hvad den kan og bør tage ved lære af i mødet med teksten og endelig nok en rekurs tilbage til 
teksten for at se, hvad den nu let ændrede retoriske teori kan sige om den. Fokuspunktet er på det, Phelan kalder "judgements", hvorved han forstår de domme, der fældes dels inde i en fortællings univers, dels af læseren over hændelser i den fortalte verden. Det særligt vellykkede ved Phelans omgang med Kafkas drilske tekst viser sig i den omhu og omtanke, hvormed Phelan bevæger sig frem og tilbage mellem tekstens singularitet og teoriens generaliseringer. Phelans læsning forbliver ærlig over for dens egne iagttagelser, selv hvor de modsætter sig eller i hvert fald kræver justeringer af den retoriske teoris tiltro til, at en fortælling altid ved, hvad den vil sige, og at den har kontrol over sine virkemidler (her den overraskende slutning). I "Dommen" udpeger Phelan med stor tekstanalytisk skarphed en "stubbornness", en ureducerbar stædig antihermeneutisk rest, som udgør såvel tekstens formelle innovation som det sted, hvorfra dens "uncanny elements" udgår. Om man så, som Phelan, deraf vil slutte, at "the implied Kafka [...] wants to unsettle us because he believes it will be for our own good" (38), det afhænger nok af den enkelte læsers temperament (et forhold, som Phelan sikkert ville være den første til at anerkende).

Den retoriske narratologi spiller ligeledes en stor rolle i Jacob Lothes fine læsning af "I Straffekolonien". I en formelt-historisk analyse viser Lothe anvendeligheden af en række af de centrale begreber fra Phelans tilgang. Indrammet af sikre indplaceringer i forhold til receptionen af Kafkas lange novelle stiller Lothe skarpt på begyndelsen af teksten og viser, hvordan allerede den første sætning inviterer læseren ind i et spændingsfyldt tekstuelt rum, hvor "no available perspective is ethically unproblematic" (165).

Hos henholdsvis Wagner og Greve spiller de retoriske pointer noget mere tilbagetrukne roller. Førstnævnte læsning af Kafkas kineserhistorier fra 1917 konfronterer Karl Heinz Bohrers ideer om litteraturen (den virkelige litteratur med stort L) som en autonom, selvberoende og ubesmittet sfære hinsides hverdag og socialitet med en Greenblattinspireret tilgang til Kafka, som fastholder, at "Kafka's narratives are only conceivable through close analysis of precisely those cultural forms and historical events that surround them" (59).

Greves "The Human Body and the Human Being in 'Die Verwandlung" sætter (som en del andre læsninger af just den Kafka-tekst) i gang med konstateringen af, at tekstens samtidighed af familiedrama og uforklaret fysisk transformation udfordrer gængse læsemetoder. Hendes egen læsning, som hæfter sig ved forholdet mellem kroppen og sindet, kunne vinde i overbevisningskraft ved at blive konfronteret med nogle af de mange læsninger, der i forvejen eksisterer af Kafkas tekst og/eller ved at inddrage mere aktuelle fænomenologiske tilgange til spørgsmålet om forholdet mellem krop og bevidsthed.

Disse mere eller mindre erklærede retoriske tilgange til Kafka kommer til at udgøre modstemmer til den herskende opfattelse af forfatterskabet. Det gør de især ved at fastholde, at der er modstemmer i Kafkas tekster, at der er afstande mellem forfatter og fortæller, som giver plads til både ironi og sympati. Målet er dog ikke at erstatte et solipsistisk dogme med et opbyggeligt og harmoniserende, men det mere sympatiske og frugtbare sigte at skabe plads til forskellige positioner.

Hvis Booths ideer om bøger som venner ligger som en skygge bag denne første gruppe af artikler, så er det snarere Derridas og Blanchots ideer om betydningsglidningernes primat, der rumler under den anden af disse positioner, fornemmelig især i Millers læsning af Slottet og i Neumanns læsning af "Der Heizer". Miller interesserer sig for, hvordan adgangen til andre menneskers indre liv eller rettere: begrænsningen $i$ adgangen til an- 
dres menneskers indre liv, på både tematisk og formelt niveau er udslagsgivende i Slottet, såvel som i de fleste andre Kafka-tekster. Spørgsmål om mind reading eller Theory of Mind har fyldt en del i de senere års narratologiske debatter, især som følge af kognitive narratologers nybrud $\mathrm{i}$ arbejdet med bevidsthedsfremstilling i og uden for fiktion, men Miller styrer behændigt helt uden om denne diskussion. Hans pointe bliver, at Slottet "dramatizes the consequences of not being sure what other people are thinking and feeling, whatever they say" (121).

Hos Neumann drejer det sig om de udfordringer til ideen om en sammenhængende livsfortælling - og om sammenhængende fortællinger i det hele taget - som Kafkas produktion rejser, ikke mindst via prosastykket "Der Heizer". Det fungerer som bekendt både som kort selvstændig novella og angiveligt som første kapitel i den aldrig færdiggjorte Amerika og følgelig ikke rigtigt som nogen af delene. Neuman stiller skarpt på det, han opfatter som et uafgørligt spil mellem adskilte, men samtidige narrative niveauer, der udstiller uden entydigt at svare på spørgsmålet "whether there are still any narratives available for the telling of individual uniqueness, for the recounting of that inalienable "naked life"' (91).

En af de ting, der lykkes for antologien, er, at den i sit anslag og i de fleste af artiklerne styrer uden om fristelsen til at tænke i modsætninger eller konfrontationer. Når der i stedet tænkes i kiastiske figurer (Kafkas fortælleindsigter, fortælleindsigternes Kafka) skyldes det nok også positive indflydelser fra den retoriske læsnings genuine intentioner om udveksling og gensidig forståelse. Samlet set kan bogen ikke frasige sig en vis skizofreni: afstanden mellem den retoriske narratologis sympatiske, men ikke altid uproblematiske tiltro til meddelelsens primat og kafkaforskningens mindre opbyggelige raids ned i meningsløshedens mudrede dybder bliver ikke nødvendigvis mindre, men den bliver synlig og dermed til at tænke med.

Opsummerende: Med internationalt anerkendte eksperter i god form, en stram redaktion (stort set ingen artikler falder igennem) og et professionelt udført stykke boghåndværk (udstyr, opsætning, alle Kafka-citater i tosproget gengivelse osv.) giver redaktørerne af Frank Kafka: Narration, Rhetoric \& Reading den interesserede læser en tur på litteraturkritikkens første klasse. At der også i disse luftlag hersker meget forskellige udlægninger af en af de mest kanoniserede moderne forfattere skal ikke ligge denne udgivelse til last; tværtimod står det som en af dens fortjenester, at forskellige positioner her står skarpt aftegnede, klar til at blive mødt af nye indvendinger.

Anmeldt af Stefan Iversen 